\title{
Research on College English Teaching Model under the Computer Environment
}

\author{
Ya'nan Zhao, Cuiling Zhao \\ Baoding University, Baoding, China \\ Email: zhaoyanan876@sina.com
}

How to cite this paper: Zhao, Y.N. and Zhao, C.L. (2019) Research on College English Teaching Model under the Computer Environment. Social Networking, 8, 104-111. https://doi.org/10.4236/sn.2019.82007

Received: March 14, 2019

Accepted: April 25, 2019

Published: April 28, 2019

Copyright $\odot 2019$ by author(s) and Scientific Research Publishing Inc. This work is licensed under the Creative Commons Attribution International License (CC BY 4.0).

http://creativecommons.org/licenses/by/4.0/

\section{cc) (i) Open Access}

\begin{abstract}
The growing update of computer and global technology provides the raw energy for college English teaching to start a revolution and development. How to deal with the teaching methods by using computer network to build a pluralistic system of interactive teaching for college English curriculum is a serious problem. This paper combines the characteristics of college English teaching, exploring the teaching ways of teaching mode and multi-interaction network of college English. Besides, it also reviews the evidence which is based on independent learning theory and several learning models, analyses the relationship between the advantages of computer network teaching and learning ability of students and enhances the benefits between teaching in practice and computer networks teaching. According to the research and survey of the College English Teaching Model of a University, it validated the role in promoting new teaching model to improve students' self-learning ability.
\end{abstract}

\section{Keywords}

English Teaching, Computer Environment, Teacher-Center-Learning, Student-Centered-Learning, Learning Strategies

\section{Introduction}

Today, with the rapid development of science and technology, especially with the continuing update of computer and network information technology, the domestic model of English teaching and method has witnessed a tremendous change. Modern teaching method of learning a foreign language is no longer a simple model of classroom teaching, and the "indoctrination" method cannot be as effective as cultivating the initiative of students. Therefore, how to combine the advantages of computer, network technology, and modern teaching methods to train talents who can adapt the modern needs of a new era has become an 
important issue right before our eyes. Every English teacher in the college must catch up with the development of times, and try to use computer technology and information network technology in teaching foreign languages to explore the model of College English Teaching under the new situation [1].

Teaching English is an integral part of higher education, and a basic compulsory course for college students. College English Teaching is a thing which uses knowledge of English and application skills, learning strategies and intercultural communication as the main content, uses linguistics and the teaching theory of foreign language as the guidance, also is combined with a teaching system which has several modes and methods of teaching. Faced with the impact of the present era, we must change the ideas of our teaching methods of education, we should focus on cultivating the ability of English integrated use of students, so that they can carry out their future work and communication in spoken and written aspect effectively, improving their ability of independent learning. On the other hand, we must use advanced teaching model to combine the traditional classroom teaching methods with the modern teaching methods [2].

The core of reforming the college English model is reforming the model of traditional teaching. We should change the form from the "teacher-centered" to "student-centered", using networks, being personalized, and being independent of the model of learning. In the environment of computer network teaching, we can shift to the computer and classroom gradually to the self-learning model, helping students to cultivate their autonomous learning ability and individualized learning. Because of the universal use of computer and network technology, students are no longer confined to the classroom, they can also learn and practice, counsel and test through computer networks, this helps to develop and enhance their habits of self-learning [3].

\section{State of the ART}

\subsection{Computer}

Computer, It can be used in numerical calculation and logical operations. Also it has a memory function to save things. It can be run by the procedure. It is an automatic device with high-speed mass data processing among the modern electronic devices. It is made by hardware and software systems, consisting of a computer without installing any software. So it is called bare metal. It can be divided into five 0 types: supercomputers, industrial control computer, a network computer, a personal computer and embedded computer. And there are some more advanced computers like biological computer, photonics computers and quantum computers etc. [4].

Computer is the invention of John von Neumann. It is the most advanced science and technology in the $20^{\text {th }}$ century's, the production of computers has an extremely important impact on human activities and social activities, its strong vitality and rapid development is one of the inventors. From the research of initial military, the application of it should be extended to all areas of society, mak- 
ing up the formation of large-scale computer industry. With the progress of technological over the world, this causes a profound social driving change. Now the computer has become an important tool for the information society and it has been around the schools, enterprises units, also entering homes of ordinary people [5].

\subsection{English of College}

The target of college English teaching is to train the ability of students to use English, especially the ability of listening and speaking. So they can use English in oral and written communication effectively in their future work and social interactions, while enhancing the ability of independent learning, improving their cultural awareness. After satisfying the basic requirements, through learning, they can get a certain extent for news dissemination, visual arts, the exchange of information and other skills of professional English which satisfy the requirements of professional English disciplines to adapt the development of social and the exchanges of international needs [6].

\section{Methodology}

In recent years, with the gradual improvement of multimedia technology, the count has been applied to the machine and it has created a new field. In the $21^{\text {st }}$ century, the modern education is not only a traditional model of "chalk and mouth", a personal computer (PC) with modern educational technology and multimedia will be introduced into the field of teaching, such as Computer-Aided instruction (CAL) and Computer Managed Instruction (CMI) has become a worldwide trend in the field of educational research and future teaching. Multimedia classroom of networks make full use of the latest computer network and multimedia technology today, it is vividly reflected in the monotony of sound, images, video, animation, etc. Through the combination of computer network technology, the real-based communications and discussion make this new teaching methods become possible [7].

New Requirements of "College English Curriculum" requires all the universities should make full use of multimedia and network technology, new teaching model should improve the existing teachers in a single classroom teaching. The new teaching model should be based on modern information technology, especially network technology to support English teaching without the restrictions of time and place on the development of personal learning and self-learning. The new model should display the principle of practicality, which is combined knowledge and interest in teaching English expression. And this way can fully mobilize the enthusiasm of teachers and students, in particular, to establish the dominant position of the students in the teaching process. New technical teaching model should reflect the interaction, implementation, and the ease of use. In addition, the new teaching model should not only use full of modern information technology, but also considerate to inherit the best parts of existing models. 
Form simply teaching by using books to use recording technology, voice teaching and audio-visual teaching to the current multimedia teaching and online teaching, network technology has changed the teaching model, teaching methods in lots of aspects, teaching methods, teacher-student relationships, learning models proposed new challenges. In order to explain the network teaching model better, this article use two consecutive semesters, in the form of a questionnaire survey of more than three hundred students in one school, and the questionnaire including three questions. They are 1) Are you satisfied with the multi-media in the college? 2) Are you satisfied with the online teaching? 3) Are you satisfied with the MOOC? And the following is the survey of the satisfaction of the curriculum of network teaching model, as shown in Table 1.

Based On the Findings, the satisfaction of network teaching model curriculum is in the trend of rising, due to the learning model in the teaching of college English and the model of network environment are very different from the model that the high school students used to be, so in the early part of the learning, students are different to adapt this phenomenon, but with the gradual understanding of learning and adaptation.

\section{Result Analysis and Discussion}

Teachers use modern educational technology, develop and use English teaching resources, such as images, audios and videos, to rich teaching content and form, promoting students' learning in classrooms; using computers and multimedia educational software to explore new teaching model to promote student's personal habits, also using radio and television, all kinds of English newspapers, libraries and network resources to create learning conditions for students. Based on Multimedia and computer teaching Model to help students to know new English teaching model design is the requirement for College English Curriculum [8]. Emphasizing personal teaching and learning, and make full use of computer can duplicate independent training, listening and speaking. Teachers can through classroom guidance, teaching reading, writing, translating the knowledge and skills to enable students under the guidance of teachers, according to their own characteristics, level, time, choose the right learning content, with the help of computer, to improve their English comprehensive practical ability rapidly to achieve the best learning results [9]. Using Multimedia technology in

Table 1. Network teaching mode curriculum sat is faction (\%).

\begin{tabular}{cccc}
\hline & Satisfaction & General & Dissatisfied \\
\hline The first survey & 73 & 21 & 8 \\
Second survey & 75 & 20 & 5 \\
The third survey & 74 & 23 & 3 \\
Fourth survey & 76 & 20 & 4 \\
Fifth survey & 79 & 19 & 2 \\
\hline
\end{tabular}


teaching, its vivid image drawings can fully mobilize a variety of sensory including people's ears, eyes, mouth, hands, etc. At the same time, the interactive Multimedia systems, as student-centered spatial information, in the process, students will feel the real formation of the image and interesting knowledge, to stimulate student interest in learning. Multimedia teaching software provides a wide, concrete, vivid, vision image and video information to enable students of establishing a strong emotional knowledge better, mobilizing student's initiative and their enthusiasm of thinking, helping students to understand and learn skills of intelligent development.

The biggest advantage of the Internet is a wealth of information resources, which allows students to get access to a wide range of information on all aspects, students are no longer limited to the vision of the content of the book, and it is convenient for them to master knowledge base, dare to put forward their spirit of innovation. In the online open network teaching platform and personal teaching blog, a number of related learning materials links to all kinds of English learning website, CET and IELTS English PubMed information and data information, cultural knowledge, work, etc. uploaded to the online teaching and personal teaching platform, students' learning and collaborative learning on the Internet. In this process, teachers can also build self-learning network platform in multimedia network classroom on the basis of student's needs and level of knowledge and learning. Learners through the network, the library has network teaching platform to realize the independent learning and cooperative learning exercise, according to their own learning methods, their favorite contents, their own interests, and more learning experiences, gaining more knowledge in the communication with teachers. Students achieve selflearning and teachers through the network teaching platform, we can break the limitations of textbooks and teachers, to choose learning resources for students to selflearning. According to their learning needs, they can also create their own blog by contacting with teachers or students to form their own groups, building a learning community, discussing with each other, to make up for each other's shortcomings, overcoming their learning difficulties, improving their English together. With the support of the new model and modern information technology, embodying the principle of practical English teaching, interests and cultural integration, and fully mobilized enthusiasm of teachers and students, in particular in establishing the dominant position of students in the teaching process. Meanwhile, the new teaching model not only inherits modern information technology, but also inherits the best part of the existing teaching model reasonably. Specific conditions of students can be seen in Table 2 .

Teachers use modern educational technology, to develop and use English teaching resources, such as images, audios and videos, the rich teaching content and form, promoting students' learning in classrooms; using of computers and multimedia educational software, exploring new teaching model to promote their personal development and use radio and television, all kinds of English 
Table 2. Student test information natural.

\begin{tabular}{cc}
\hline Sort by & Natural information \\
\hline Now major & Institute of technology 52: Literature and History 99 \\
School year & Freshman 97 ; sophomore 56 \\
To students & 130 students from the city; students from rural and township of 170 people \\
\hline
\end{tabular}

newspapers, libraries and network resources to create learning conditions for students. Classroom and computer based multimedia college English teaching model is a design to help students on the requirements of a new teaching model of college English. It emphasizes individualized teaching and learning, and makes full use of the characteristics of computer which can be used in listening and speaking training independently, and teachers can through classroom guidance, reading, writing, translating the knowledge and explaining skills to enable students under the guidance of teachers, according to their own characteristics, level, time, choosing the right learning content, with computers, to improve their English comprehensive practical ability rapidly to achieve the best learning results. Besides, in the process of the use of multimedia teaching technology, vivid schema can fully mobilize the students' ears, eyes, mouth, hands and other senses simultaneously, interactive multimedia system can be formed in student centered spatial information, and student will have the knowledge of the true image and cultivate their interests in learning. Multimedia educational software provides a lot of rich, vivid, intuitive graphic video information, so that students can build a strong emotional knowledge garage, which cultivates students' learning initiative, active student' thoughts, to help students master skills and intellectual development. The biggest advantage of the Internet is a wealth of information resources, it allows students to have a wide range of information on all aspects. So the visual field of students is no longer confined to the contents of the books, it is convenient for students to master sufficient knowledge base, being dare to put forward their spirit of innovation. In the online open network teaching platform and personal teaching blog, a number of related learning materials are upload on network teaching platform and teaching personal blog, so that students can develop selflearning and collaborative learning online, In this process, the teacher can know better according to the situation of our students. Computer network teaching model realizes a "one to one" teaching philosophy, the face of a computer is like an English teacher's face. Students can enjoy listening to the explanations of teachers, can communicate with teachers freely. According to the requirements of "New Curriculum", combined with the actual situation of our students, strengthen the basic knowledge of English of students, cultivate their English composited ability and selecting ability in particular to strengthen the ability of listening, speaking, reading. So that students can communicate effectively in oral and written aspect. Shanghai Foreign Language Education University choose "College New Version of English" as its textbook, using the new version of College English teaching systems and multimedia 
courseware educational software systems. In the classroom, teachers make full use of, multimedia courseware illustrations, audio-visual advantage, and a lot of interesting design activities so that students can become a key figure in the classroom, teachers through the active participation and training of students, guiding them to increase students' self-learning ability gradually to realize the background of entertaining. In the class, students can choose classes according to their own foundation, rely on accurate and convenient network learning system, to select class which they are interested in, also they can use the computer learning software practice listening and speaking ability repeatedly. Teachers also have a plan, exploring students' work online step by step, inspect work, answer their questions, doubts, tests, guiding students to learn independently effectively, which offers a great help to cultivate students' English comprehensive ability and improvements. In order to understand the computer network environment of college English teaching, cultivating self-learning ability of students, improving students' ability to use English, the author use the form of a questionnaire survey of more than700 students in their school for two consecutive semesters. Student who took questionnaires processed in the environment and the form and content of the multimedia network teaching; student' satisfaction with teaching network systems and multimedia courseware; student satisfaction in the computer network environment of college English teaching and learning. The author use a questionnaire, divided into five questionnaire surveys. Survey results show that, because the teaching model of college English is different from the model of learning when students were in high school, so at the beginning of learning, some students feel it difficult to adapt, but with the gradual understanding and adaptation, in the form of satisfaction teaching content and increasing trend, according to teaching network systems and multimedia courseware, because of its vivid, multisensory impact collection as a whole, the students are very interested in it at first, but with further research, students are exposed to richer and related materials, and the novelty faded, the satisfaction of multimedia network teaching system has a slight decline: according to the increased teaching effectiveness from satisfaction survey results, it has showed a trend which can be clearly seen: students have $80 \%$ of positive attitude with a new student teaching model.

\section{Conclusion}

Reforming teaching mode is the core of college English teaching reform. We should be in a timely manner from the "teacher-centered teaching" to "student-centered learning" change, realizing networks, personalized, and autonomous learning model. College English teaching is a systematic project, which is influenced by students' English proficiency and learning strategies, teaching philosophy and professional quality of teachers and teaching environment, teaching materials, and many other factors and constraints. In this sense, the teaching model is also impossible and it should not have fixed methods and 
procedures. Although the network teaching model has considerable operational and practical significance to college English teaching, to make full use of this model, both teachers and students need to cooperate and coordinate. Only by the reasonable use, individualized teaching, and spare no effort to optimize a variety of teaching methods can we improve the quality of college English teaching, cultivate "integrated" talent with the knowledge of English and have a high capacity, learning ability, good logical thinking ability and certain organizations creative ability.

\section{Conflicts of Interest}

The authors declare no conflicts of interest regarding the publication of this paper.

\section{References}

[1] Bardvi-Harlig, K. (2000) Tense and Aspect in Second Language Acquisition: Form, Meaning, and Use. Language Leaning. A Journal of Research in Language Studies, 50, 1-5.

[2] Gardner, R.C. and Lambert, W.E. (1959) Motivation Variables in Second Language Acquisition. Canadian Journal of Psychology, 13, 266-269. https://doi.org/10.1037/h0083787

[3] O’Malley, J.M. and Chamot, A.U. (1990) Learning Strategies in Second Language Acquisition. Cambridge University Press, Cambridge, 56-59.

[4] Olinger, H.C. (1939) Methodology in Language Teaching. The French Review, 12, 323-348.

[5] Bpéen, M.P. and Candling, C.N. (1980) The Essentials of a Communicative Curriculum in Language Teaching. Applied Linguistics, 1, 89-112. https://doi.org/10.1093/applin/1.2.89

[6] Biber, D., Conrad, S. and Reppen, R. (1994) Corpus-Based Approaches to Issues in Applied Linguistics. Applied Linguistics, 15, 169-189. https://doi.org/10.1093/applin/15.2.169

[7] Jonassen, D.H. (2002) Engaging and Supporting Problem Solving in Online learning. Quarterly Review of Distance Education, 3, 9-12.

[8] Stubbs, M. (2001) Texts, Corpora, and Problems of Interpretation: A Response to Widdowson. Applied linguistics, 22, 149-172. https://doi.org/10.1093/applin/22.2.149

[9] Chambers, A.T. and Bax, S. (2006) Making CALL Work: Towards Normalization. System, 8, 22-26. https://doi.org/10.1016/j.system.2006.08.001 